Scientific Electronic Archives

Issue ID: Sci. Elec. Arch. Vol. 15 (3)

March 2022

DOI: http://dx.doi.org/10.36560/15320221501

Article link: https://sea.ufr.edu.br/SEA/article/view/1501

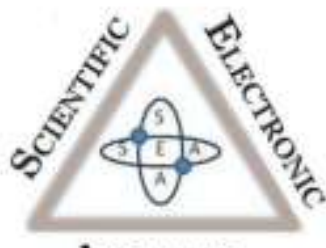

ARCHIVEs

ISSN 2316-9281

\title{
Studies on martial arts, fights and sports combat with police: a systematic review
}

\author{
Corresponding author \\ Jonatas Deivyson Reis Da Silva Duarte \\ Federal University of Mato Grosso \\ Costa Verde Military Police Academy \\ jonatas00013@hotmail.com
}

\author{
Almir De França Ferraz \\ Faculty of Technology of Ipê \\ Costa Verde Military Police Academy
}

\begin{abstract}
Introduction: The profession of a military police officer is to maintain order and that is why he may find himself in stressful and life-threatening situations. Although they undergo specific military training, martial arts, fighting and combat sports (MA/F/CS) is a recommended way to maintain health and additional training for these military police officers. Objective: To analyze through a systematic review the studies carried out on MA/F/CS with police officers. Methods: The systematic search for this study was conducted through the Pubmed, Scielo, Lilacs, Medline and Portal de Periódicos da Capes (Brazilian indexing portal). Results: Five articles were included that showed the relationship of how the MA/F/CS can improve the performance of police officers, reducing stress, anxiety, injuries and medical certificates. Conclusion: The regular practice of $M A / F / C S$ as an additional form for police officers appears to improve the performance of their duties. However, future studies should analyze health and quality of life markers in this population. Keywords: Militarism, Physical Education, Self Defense, Public Security.
\end{abstract}

\section{Introduction}

Police officers are authorities legally created to maintain order (FERRAZ et al., 2020) and drug seizure (KANKAAPAA et al., 2016). The work of the military police deals with various urban conflicts, which must be done in a sensible, legal and technical way (JUNIOR et al., 2020). The task of enforcing laws can generate psychological stress at work, which can lead to problems of depression (GARBARINO et al., 2013) and heart attack (HINE; CAREY, 2021).

Some police have sedentary behavior and obesity (FERRAZ et al., 2020), this becomes worrying in terms of health. Hine and Carey (2021) defend the importance of strategies for preventing police deaths. A good strategy for this is the regular practice of physical exercise, as according to Almeida et al (2014) it is a way to maintain health and healthy longevity being the MA/F/CS one of the manifestations of physical exercise (WASIK; JACEK; WÓJCIK, 2017), these sports can be practiced for both competitive, health and self-defense purposes (DA SILVA DUARTE et al., 2021; BALL; MARTIN, 2012) .
By definition, a fight is any situation of opposition between two or more people, whereas martial arts are combat activities with a philosophical basis (FRANCHINI; DEL VECCHIO, 2012). Martial arts seek physical, ethical and spiritual improvement (CYNARSKI et al., 2015) with self-defense techniques, in contrast, combat sports modalities focus on sports competitions (JOHNSON; HÁ, 2015).

In this sense, with industrialization and urbanization, crimes are increased and, therefore, police officers must undergo training by the $M A / F / C S$ (JEANG, 2015). It is recommended that the facilities allow the practice of diversified styles of $M A / F / C S$ (JEANG, 2015). Therefore, in view of the importance of additional training for $M A / F / C S$ in police officers, the objective of this systematic review is to survey and analyze the original studies related to the topic.

\section{Contextualization and analysis}

The first phase of this review was to search the indexing portals Pubmed, Scielo, Lilacs, Medline and Portal de Periódicos da Capes with the 
keywords: "Police and Martial Arts" and "Police and Sport Combat", the period was not established. initial search. The search for articles was from $26 / 07 / 2021$ to $28 / 07 / 2021$. In the second phase, the titles and objectives of the studies were read to analyze the possible compatibility with the objective of the work. In cases of doubt, complete summaries were read.

Inclusion criteria

Original articles were included, which have as part of the police sample universe and that has $\mathrm{MA} / \mathrm{F} / \mathrm{CS}$ as the analyzed variable. Articles based on the objectives and inclusion criteria.

A total of 3,482 documents were identified from 1951 to 2021 when the keywords were used, however, in the Portal de Periódicos da Capes most documents were not scientific articles, hence the expressiveness of exclusion. After applying the eligibility criteria, ten articles were selected, after analyzing the repeated and review articles, five remained (Flowchart 1 ).

The sample size of the studies was $1,402,659$ volunteers. Table 1 shows the types of studies, sample quantities, objectives and results/conclusion. Four studies were found related to the psychological impact (anxiety and confidence) at work and only one study on certificates and injuries.

Most studies were carried out in Europe Germany, United Kingdom and Netherlands), and the Netherlands was the country with the most original studies carried out (two) according to this systematic review. In America, a study was found in the United States (Table 2).

Results of files found in databases Pubmed $(n=11)$, Scielo $(n=0)$, Medline $(n=0)$ e Portal de periódicos da Capes $(n=3,470)$

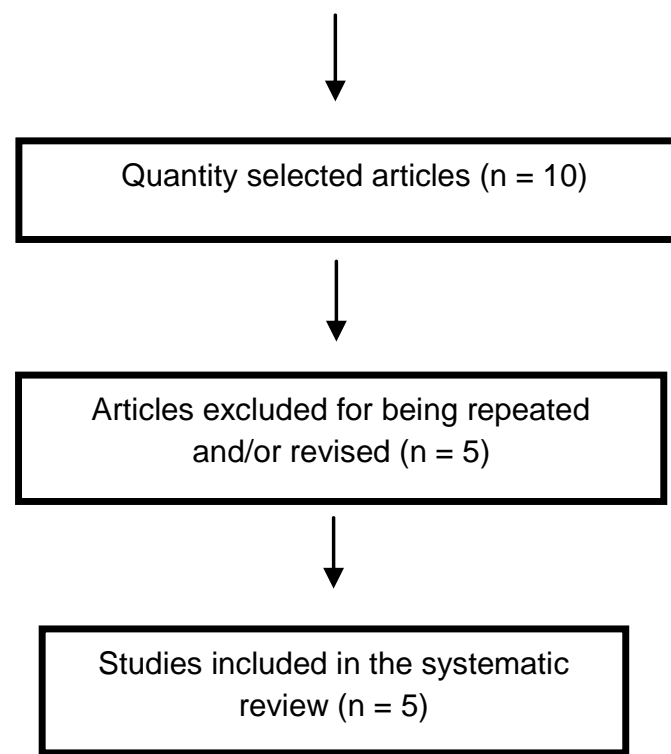

Figure 1. Procedures used in the search and selection of articles 
Da Silva Duarte et al. Studies On Martial Arts, Fights And Sports Combat With Police: A Systematic Review

Table 1 - Main methodological characteristics and results of systematic review studies involving martial arts, fights and combat sports with police officers

\begin{tabular}{|c|c|c|c|c|}
\hline Authors (year) & Objective & Kind of study & Sample & Results/Conclusion \\
\hline $\begin{array}{l}\text { Jiménez et al } \\
(2020)\end{array}$ & $\begin{array}{l}\text { Analyze whether the } \\
\text { course of operational } \\
\text { tactical procedures (with } \\
\text { martial arts elements) } \\
\text { decreases medical } \\
\text { certificates and injuries }\end{array}$ & Cohort (14 years) & $\begin{array}{l}\text { Men }(n=154) \\
\text { and women }(n= \\
8)\end{array}$ & $\begin{array}{c}\text { There was a decrease in medical } \\
\text { certificates and incidence of } \\
\text { injuries, during and after the } \\
\text { course. }\end{array}$ \\
\hline $\begin{array}{l}\text { Renden et al } \\
(2015)\end{array}$ & $\begin{array}{l}\text { Through an online } \\
\text { questionnaire, analyze } \\
\text { the perception of police } \\
\text { officers in dealing with } \\
\text { violence on duty }\end{array}$ & Transverse & $\begin{array}{c}\text { Men }(\mathrm{n}=741) \\
\text { and women }(\mathrm{n}= \\
180)\end{array}$ & $\begin{array}{l}61.4 \% \text { of the sample never } \\
\text { practiced martial arts. Officials } \\
\text { reported that self-defense and } \\
\text { prison skills training are } \\
\text { moderately usable and having } \\
\text { additional stressful experiences } \\
\text { helped improve self-perceived } \\
\text { performance. }\end{array}$ \\
\hline $\begin{array}{l}\text { Renden et al } \\
(2015 a)\end{array}$ & $\begin{array}{l}\text { Investigate whether } \\
\text { officers experienced in } \\
\text { MA/F/CS training (in } \\
\text { their leisure time) } \\
\text { perform better in } \\
\text { (simulated) prison and } \\
\text { self-defense scenarios } \\
\text { under low and high } \\
\text { pressure compared to } \\
\text { officers who rely only on } \\
\text { regular police training }\end{array}$ & Experimental & $\begin{array}{c}\text { Men }(\mathrm{n}=59) \\
\text { and women }(\mathrm{n}= \\
7)\end{array}$ & $\begin{array}{c}\text { There was an improvement in the } \\
\text { performance of regular MA/F/CS } \\
\text { practitioners (krav maga, } \\
\text { kickboxing, karate and jiu-jitsu) } \\
\text { only in situations of high anxiety } \\
\text { compared to police officers who do } \\
\text { not practice MA/F/CS. However, } \\
\text { the performance of both worsened } \\
\text { in the high anxiety situation. }\end{array}$ \\
\hline Towers (2018) & $\begin{array}{l}\text { Examine whether } \\
\text { MA/F/CS training } \\
\text { impacts confidence in } \\
\text { police practice }\end{array}$ & Transverse & $\begin{array}{l}\text { Police officers ( } n \\
=1,064 \text { ), the } \\
\text { authors do not } \\
\text { specify the } \\
\text { genders, they } \\
\text { only state that } \\
92 \% \text { of the } \\
\text { sample are men }\end{array}$ & $\begin{array}{l}\text { Police officers who practice } \\
\text { MA/F/CS are more confident in } \\
\text { carrying out their duties. }\end{array}$ \\
\hline $\begin{array}{l}\text { Staller et al } \\
\quad(2017)\end{array}$ & $\begin{array}{l}\text { Analyze the possible } \\
\text { attention bias to risky } \\
\text { situations and trait } \\
\text { anxiety in police officers. }\end{array}$ & Transverse & $\begin{array}{l}\text { Men }(n=152) \\
\text { and women }(n= \\
53)\end{array}$ & $\begin{array}{l}\text { Police officers and non-MA/F/CS } \\
\text { practitioners, martial artists, and } \\
\text { non-police and non-martial arts } \\
\text { individuals (control group) had no } \\
\text { difference regarding threat-related } \\
\text { attention bias. In contrast, the } \\
\text { control group had higher levels of } \\
\text { trait anxiety }\end{array}$ \\
\hline
\end{tabular}

Sources: The authors

Note: $\mathrm{n}=$ number of participants; $\mathrm{MA} / \mathrm{F} / \mathrm{CS}=$ martial arts, fighting and combat sports

Table 2 - Nationality of police officers studied in the systematic review

\begin{tabular}{lc}
\hline Authors and year & Country \\
\hline Jiménez et al (2012) & Spain \\
Renden et al (2015) & Netherlands \\
Renden et al (2015a) & Netherlands \\
Towers (2018) & United States \\
Staller et al (2017) & Germany and United Kingdom \\
\hline
\end{tabular}

Source: Authors 


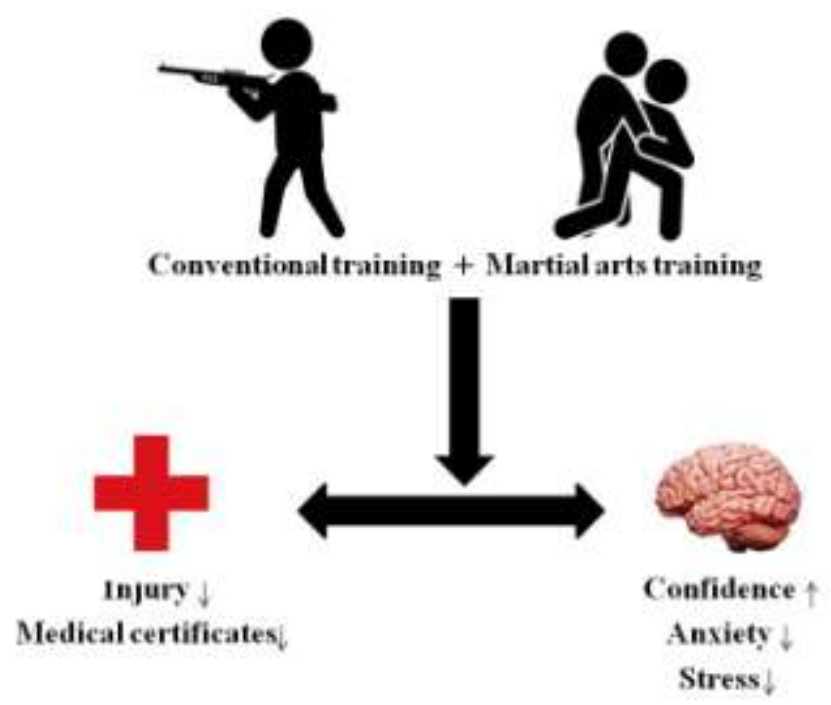

Figure 1 - The benefits of additional training in martial arts, fighting, and combat sports for police officers

As far as we know, this is the first study to analyze the studies carried out on the MA/F/CS theme with police officers. Only five original studies were found, which was not expected. Our main findings are that all studies analyzed how MA/F/CS can help police officers in carrying out their duties even in stressful situations (RENDEN et al., 2015; RENDEN et al., 2015a; TORRES, 2018; STALLER et al., 2017) and how its practice can prevent injuries and reduce medical certificates (JIMÉNEZ et al., 2020). Figure 1 illustrates the main findings of this study.

Police officers are often exposed to situations of conflicts and arrests with violent criminals (VIOLANTI; DOUGLAS, 1999), and police officers who work in urban areas tend to have greater problems (JEANG, 2015). Due to these problems, police officers must be proficient in a variety of self-defense techniques (O'NEILL et al., 2019; KÖRNER; STALLER, 2018). However, police training must be based on simulations of real situations for greater transfers and be preparing physiological and psychological mechanisms (ANDERSON et al., 2016).

In the study by Renden et al (2015), in the perception of some police officers, traditional training is moderately usable and real experience becomes important. Police officers who practice martial arts in their free time tend to have more confidence in carrying out the demands of their work (TORRES, 2018). In a controlled environment of high anxiety, officers who practice martial arts fared better (RENDEN et al., 2015a).

Unfortunately, there is a record in the scientific literature of police officers with sedentary behavior (FERRAZ et al., 2020). This may be related to the incidence of obesity (ARREDONDO, 2018), hypertension (YATES et al., 2021) and type 2 diabetes mellitus (YU et al., 2016) in this population. Regular physical exercise is a way of treating and preventing these pathologies and improving mental health (FERNADEZ GUIJARRO, 2019). A fourteenyear cohort study showed that 150 minutes per week of rigorous exercise improves health and longevity (ALMEIDA et al., 2014).

The regular practice of MA/F/CS is an important aspect for health and fitness. For Irving, Orr and Pope (2019), police officers must be conditioned to carry out their tasks. Another important aspect of the practice of MA/F/CS in police officers is the reduction of injuries during work and medical leaves (JIMÉNEZ et al., 2020). The decrease in injuries by these police officers may be because the techniques learned in MA/F/CS have the effect of preventing injuries caused by everyday situations (for example, falling) (BOGUSZEWSKI et al ., 2015). On the other hand, MA/F/CS training can cause injuries due to its inherent characteristic of contact, in this sense, it is up to MA/F/CS teachers to seek to avoid situations of heavy physical contact and high volumes of training to prevent possible injuries avoidable during training (JAMES, 2014).

The decrease in medical certificates found in the study by Jiménez et al. (2020) may be because the regular practice of physical exercise contributes to the health status (FERRAZ et al., 2018). Studies show that the practice of MA/F/CS is a good way to improve cardiovascular health (BELO et al., 2021), bone density (ITO et al., 2017), metabolic diseases (HAMASAKI, 2016) and well- being psychological (CROOM, 2014).

In our search, few studies on the subject were found in the portals surveyed, and further studies are needed to promote the topic in question. We recommend studies that analyze aspects of the markers of quality of life, physical and mental health 
of police officers practicing MA/F/CS and not just the effect on the application of their duties.

\section{Final considerations}

There are few studies on MA/F/CS with police officers, and the studies found only analyze how their additional training can improve the performance of officers in the application of their duties. Most of them being carried out on the European continent. Additional MA/F/CS training seems to reduce anxiety in times of risk and stress, it also seems to reduce work-related injuries and medical certificates.

It is important that public safety professionals are oriented about the benefits and importance of the practice of $M A / F / C S$ to improve their health and their performance as a police officer. We recommend public safety policies that optionally offer these modalities in gyms and barracks.

\section{Recommendations}

- Investments in dojos and fitness centers in barracks and gyms.

- Offer MA/F/CS in an optional and complementary way for military police officers.

- Have periodic and scientific lectures on the benefits of regular physical exercise.

- Specialized training should be as close to real conflict situations (ANDERSON et al., 2016).

\section{References}

ALMEIDA, Osvaldo P; KHAN, Karim M; HANKEY, Graeme J; YEAP, Bu B; GOLLEDGE, Jonathan; FLICKER, Leon. 150 minutes of vigorous physical activity per week predicts survival and successful ageing: a population-based 11-year longitudinal study of 12201 older Australian men. British Journal of Sports Medicine, v. 48, n. 3, p. 220-225, 2014.

ANDERSEN, Judith P; PITEL, Marian; WEERASINGLE, Ashini; PAPAZOGLOU, Konstantinos.. Highly realistic scenario based training simulates the psychophysiology of real world use of force encounters: implications for improved police officer performance. Journal of Law Enforcement. v, 5; n. 4, p. 1-13, 2016.

ARREDONDO, Guillermo Padrón. Body mass index in a group of security forces (policemen). Crosssectional study. New Insights Obes Gene Beyond, v. 2, p. 001-004, 2018.

BALL, Kimberly; MARTIN, Jeffrey. Self-defense training and traditional martial arts: Influences on self-efficacy and fear related to sexual victimization. Sport, Exercise, and Performance Psychology, v. 1, n. 2, p. 135-144, 2012.

BELO, Wesley Rodrigues; DE CASTRO, Lucas Fenta; PALMIERU, Diego Cesar; DOS SANTOS,
Luiz Gustavo; HERRERA-VALENZUELA, Tomás; DOS SANTOS, Marco Atonio Ferreira; ØVRETVEIT, Karsten; SIMÃO, Roberto. Post-Exercise Hypotension in Brazilian Jiu-Jitsu. Sport Mont, v. 19, n. 1, p. 39-43, 2021.

BOGUSZEWSKI, Dariusz; ADAMCZYK, Jakub Grazegorz; KERBAUM, Katarzyna; ANTONIAK, Bartlomiej; OBSZYŃSKA-LITWINIEC; Anna; BIAŁOSZEWSKI; Dariusz. Susceptibility to injury during falls in women practising combat sports and martial arts. Polish Journal of Sport and Tourism, v. 22, n. 1, p. 15-19, 2015.

CROOM, Adam M. Embodying martial arts for mental health: Cultivating psychological wellbeing with martial arts practice. Archives of Budo Science of Martial Arts and Extreme Sports, v. 10, p. 59-70, 2014.

CYNARSKI, Wojciech J; YU, Jong-Hoon; WARCHOL, Krzysztof; BARTIK, Pavol. Martial arts in psycho-physical culture. Ido Movement for Culture. Journal of Martial Arts Anthropology, v. 15, n. 4, p. 3-38, 2015.

DA SILVA DUARTE, Jonatas, Deivyson Reis da Silva; RODRIGUES, Hadassa Hillary Novaes Pereira; CUNHA, Maryella, García; DE MACEDO, Anielly Florence; SALINAS, Johan Andrés Robalino; CLAUDINO, Talita Xavier; PASA, Camila; FETT, Waléria, Cristiane Rezende; FETT, Carlos Alexandre. Dietary intake in kickboxing fighters. Brazilian Journal of Development, v. 7, n. 4, p. 42409-42424, 2021.

FERNANDEZ GUIJARRO, Sara; POMAROLCLOTET, Edith; MUÑOZ, Carmem Rubio; GARCÍA, Carolina Miguel; LÓPEZ, Elena Egea; GUIJARRO, Rebeca Fernández; PÉREZ, Lidia Castán; CUADRA, Assumpta Rigol. Effectiveness of a community-based nurse-led lifestyle-modification intervention for people with serious mental illness and metabolic syndrome. International Journal of Mental Health Nursing, v. 28, n. 6, p. 1328-1337, 2019.

FERRAZ, Almir de França; DE ANDRADE, Erinaldo Luiz; VIANA, Michell Vetoraci; RICA, Roverta Luksevicius; BOCALINI, Danilo Sales; JÚNIOR, Aylton Figueira. PHYSICAL ACTIVITY LEVEL AND SEDENTARY BEHAVIOR OF MILITARY POLICE STAFF. Revista Brasileira de Medicina do Esporte, v. 26, n. 2, p. 117-121, 2020.

FERRAZ, Almir de França; VIANA, Michell Vetoraci; RICA, Roberta Luksevicius; BOCALINI, Danilo Sales; BOTTAZZA, Rafael Ambrósio; MIRANDA, Maria Luiza de Jesus; POLITTI, Fabiano; JUNIOR, Aylton Figueira. Efeitos da atividade física em parâmetros cardiometabólicos de policiais: revisão sistemática. ConScientiae Saúde, v. 17, n. 3, p. 356370, 2018. 
FRANCHINI, Emerson; DEL VECCHIO, Fabrício Boscolo. Ensino de Lutas: reflexão e propostas de programas. São Paulo: Editora Scortecci, 2012.

GARBARINO, Sergio; CUOMO, Giovanni; CHIORRI, Carlo; MAGNAVITA, Nicola. Association of work-related stress with mental health problems in a special police force unit. BMJ open, v. 3, n. 7, p. 112, 2013.

HAMASAKI, Hidetaka. Martial arts and metabolic diseases. Sports, v. 4, n. 2, p. 1-12, 2016.

HINE, Kelly A.; CAREY, Samantha. The current nature of police officer fatalities in Australia and opportunities for prevention. Current Issues in Criminal Justice, v. 33, n. 2, p. 191-210, 2021.

IRVING, Shane; ORR, Robin; POPE, Rodney. Profiling the occupational tasks and physical conditioning of specialist police. International Journal of Exercise Science, v. 12, n. 3, p. 173-186, 2019.

ITO, Igor H; KEMPER, Han C. G; AGOSTINETE, Ricardo R; LYNCH, Kyle R; CHRISTOFANO, Diego G. D; RONQUE, Enio R; FERNANDES, Rômulo. Impact of martial arts (Judo, Karate, and Kung Fu) on bone mineral density gains in adolescents of both genders: 9-month follow-up. Pediatric exercise science, v. 29, n. 4, p. 496-503, 2017.

JAMES, Lachlan P. Injury prevention strategies for mixed martial arts. Strength \& Conditioning Journal, v. 36, n. 5 , p. 88-95, 2014.

JEANG, II Hong. The Development Direction of Police Martial Arts Education. Convergence Security Journal, v. 15, n. 6_2, p. 121-127, 2015.

JOHNSON, John A.; HA, Peter. Elucidating pedagogical objectives for combat systems, martial arts, and combat sports. Ido Movement for Culture. Journal of Martial Arts Anthropology, v. 4, n. 15, p. 65-74, 2015.

JUNIOR, Adalberto Correa; FERRAZ, Almir França; SILVA, Rosilene Andrade; FETT, Carlos Alexandre. "Pronto para Guerra" e o "Olhar Clínico nas Lutas, Artes Marciais e Modalidades de Combate. Homens do Mato-Revista Científica de Pesquisa em Segurança Pública, v. 20, n. 1, p. 238-245, 2020.

KANKAANPÄÄ, Aino; ARINIEMI, Kari; HEINONEM, Mari; KOUPPASALMI, Kimmo; GUNNAR, Teemu. Current trends in Finnish drug abuse: Wastewater based epidemiology combined with other national indicators. Science of the Total Environment, v. 568, p. 864-874, 2016.

KÖRNER, Swen; STALLER, Mario S. From system to pedagogy: towards a nonlinear pedagogy of selfdefense training in the police and the civilian domain. Security Journal, v. 31, n. 2, p. 645-659, 2018.

O'NEILL, John; O’NEILL, Dawn A; WEED, Katelun; HARTMAN, Mark E; SPENCE, Willian; LEWINSKI, William J.. Police academy training, performance, and learning. Behavior analysis in practice, v. 12, n. 2, p. 353-372, 2019.

RENDEN, Peter G; NIEUWENHUYS, Arne; SAVELSBERGH, Geert J. P; OUDEJANS, Raôul R. D. Dutch police officers' preparation and performance of their arrest and self-defence skills: A questionnaire study. Applied Ergonomics, v. 49, p. 8-17, 2015.

RENDEN, Peter G; LANDMAN, Annemarie; SAVELSBERGH, Geert J. P; OUDEJANS, Raôul R. D. Police arrest and self-defence skills: performance under anxiety of officers with and without additional experience in martial arts. Ergonomics, v. 58, n. 9, p. 1496-1506, 2015a.

STALLER, Mario S; ZAISER, Benjamin; KORNER, Swen; COLE Jon C. Threat-related attentional biases in police officers and martial artists: investigating potential differences using the E-Stroop and dot probe task. Sage open, v. 7, n. 2, p.1-17, 2017.

TORRES, Jose. Predicting law enforcement confidence in going 'hands-on': The impact of martial arts training, use-of-force self-efficacy, motivation, and apprehensiveness. Police Practice and Research, v. 21, n. 2, p. 187-203, 2020.

VERA JIMÉNEZ, José Carlos; FERNÁNDEZ, Franccisco; AYUSO VILACIDES, Jesus; LORENTE ACOSTA, José Antonio. Evaluation of the police operational tactical procedures for reducing officer injuries resulting from physical interventions in problematic arrests. The case of the Municipal Police of Cádiz (Spain). Int J Occup Med Environ Health, v. 1, n. 33, p. 35-43. 2020.

VIOLANTI, John M.; PATON, Douglas. Police trauma: Psychological aftermath of civilian combat. Charles C Thomas Publisher, 1999.

WASIK, JACEK; WÓJCIK, A. Health in the context of martial arts practice. Physical Activity Review, v. 5, p. 91-94, 2017.

YATES, James D; ALDOUS, Jeffrey W F; BAILEY, Daniel P; CHATER, Angel M; MITCHELL, Andrew C S; RICHARDS, Joanna C. The Prevalence and Predictors of Hypertension and the Metabolic Syndrome in Police Personnel. International Journal of Environmental Research and Public Health, v. 18, n. 13, p. 1-11, 2021.

YU, Hao; LIU, jin-chuan; YA-JIAO, Fan; LI, Chen; ZHANG, Lin-xin; CHEN, Xi; YUE, Song; LU, Wen-li; 
YANG, Xi-lin; TANG, Nai-jun. Association between occupational stressors and type 2 diabetes among Chinese police officers: a 4-year follow-up study in Tianjin, China. International archives of occupational and environmental health, v. 89 , n. 2, p. 277-288, 2016. 